\title{
Gas-assisted gravity drainage process for improved oil recovery in Bao Den fractured basement reservoir
}

- Nguyen Van Tuan ${ }^{1,2}$

- Tran Van Xuan ${ }^{2}$

${ }^{1}$ Cuu Long JOC

${ }^{2}$ Faculty of Geology and Petroleum Engineering, Ho Chi Minh city University of Technology, VNU-HCM

(Manuscript Received on August 10 $0^{\text {th }}, 2015$; Manuscript Revised on October $20^{\text {th }}, 2015$ )

\begin{abstract}
Gas injection has been widely used for Improved Oil Recovery (IOR)/ Enhanced Oil Recovery (EOR) processes in oil reservoirs. Unlike the conventional gas injection (CGI) modes of CGI and Water Alternating Gas (WAG), the Gas-Assisted Gravity Drainage (GAGD) process takes advantage of the natural segregation of reservoir fluids to provide gravity stable oil displacement. It has been proved that GAGD Process results in better sweep efficiency and higher microscopic displacement to recover the bypassed oil from un-swept regions in the reservoir. Therefore, dry gas has been considered for injection in fractured basement reservoir, Bao Den (BD) oil field located in Cuu Long basin through the GAGD process application. This field, with a 5-year production history, has nine production wells and is surrounded by a strong active edge aquifer from the North-West and the South East flanks. The depth of basement granite top is about 2,800 mTVDss with a vertical oil column of 1,500m. The pilot GAGD project has been designed to test an isolated domain in the BD fractured

reservoir conditions to implement GAGD. Both reservoir simulation and Lab test have been run and confirmed the feasibility and the benefit of GAGD project in the selected area.The Dry gas will be periodically injected through existing wellwith high water cut production that located in the isolated area. As the injected gas rises to the top to form a gas zone pushing GOC (gas oil contact) downward, and may push WOC (water oil contact) to lower part of this producer (or even away from bottom of the well bore) could lower down water cut when switch this well back to production mode. The matched reservoir model with reservoir and fluid properties have been used to implement sensitivity analysis, the result indicated that there is significantly oil incremental and water cut reduction by GAGDapplication. Many different scenarios have run to find the optimal reservoir performance through GAGD process. Among these runs, the optimal scenario, which has distinct target, requires high levels of gas injection rate to attain the maximum cumulative oil production.
\end{abstract} basement reservoir where there is favorable

Key word: gravity drainage, EOR/IOR, GAGD, FracturedBasement Reservoir, injection, pushing. 


\section{INTRODUCTION}

The Bao Den field is located in the Cuu Long Basin offshore southern Vietnam, 120 miles (180 kilometers) southeast of Ho Chi Minh City. The field has structure of approximately $6 \mathrm{~km}$ long and $3 \mathrm{~km}$ wide with the basement reservoir rock comprising of highly fractured granite oil bearing zone with a vertical column of $1,500 \mathrm{~m}$.

Crude oil from the subject reservoir is medium with an API gravity of \# 35.3. The reservoir pressure is 4,400 psia at 2,800 mTVDss, reservoir temperature is $270{ }^{\circ} \mathrm{F}$ $\left(130^{\circ} \mathrm{C}\right)$ and very low hydrogen Sulphide content in associated gas.

The production from this reservoir started in 2010 and all wells flowed under natural depletion.However, water breakthrough happened very soon just after one year of production. A typical phenomenon of water development in fractured basement is that once water appears, water cut will increase quickly and natural flow ceased after several weeks. Gas lift has proved to be an effective artificial lift method for this type of reservoir to maintain flow rate in term of inexpensiveness, low maintenance, low intervention cost and the ability to adjust or change operating conditions. However, with increasing water cuts and depleting reservoir energy, currently the lift gas capacity is insufficient to optimized field production. It has been urged to continue to find opportunities to increase oil production, and in particular identify any possible IOR/EOR applications. This paper proposes the implementation of an IOR technique known as Gas-Assisted Gravity Drainage (GAGD) in fractured basement reservoir (FBR), BD oil field with the ability to accelerate field production and also increase oil recovery. Before full field GAGD application, a pilot test was designed to experimentat an isolated domain in FBR, BDoil fieldincludinglab test\& reservoir simulation studies.

\section{GAS-ASSISTED GRAVITY DRAINAGE (GAGD) METHOD}

Gas-Assisted Gravity Drainage (GAGD) is a simple IOR/EOR technique in which a gas is injected into the reservoir and the in-situ oil swells until it is fully saturated, until a separate gas-cap is created. As a result of these two mechanisms, the current OWC is pushed down. The schematic of the technique and two mechanisms described at idealised conditions are illustrated in Figures $1 \boldsymbol{a} \& \boldsymbol{b}$. This "Huff and Puff"-type technique consists of the following stages:

- Shut-in producing well with high watercut,

- Inject slug of gas (plus possible closed-in period for gas dissolution and/or migration),

- Re-open well to production (with lower watercut)

The periods of gas dissolution / migration will vary according to the vertical connectivity within the fracture system.

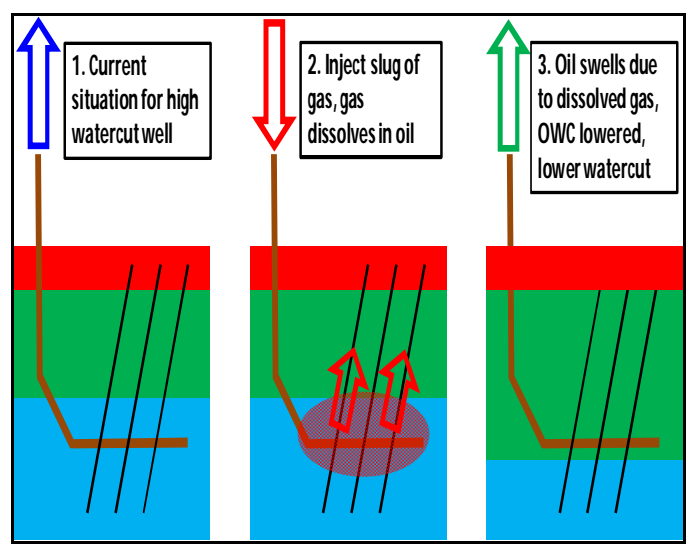

Figure 1a. Scheme showing concept of GAGD in reservoir (Undersaturated reservoir, above $\mathrm{Pb}$ ) 


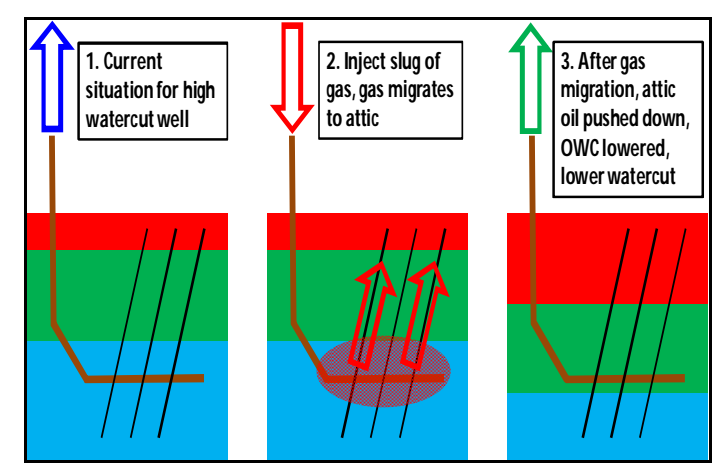

Figure 1b. Scheme showing concept of GAGD in reservoir (Saturated reservoir, below $\mathrm{Pb}$ )

\subsection{Selection Candidates for GAGD Pilot Test}

The criteria used to select the proposed well in BD fractured basement field is shown in the table 1. Note that BD oil fiel is the most appropriate field for a GAGD pilot since it consists of several isolated fault blocks (criterion \#4), in comparison to the other fields.

A small, isolated fault block will allow a quicker response for a particular slug size, as the OWC will be pushed down further. The two wells, BD-12P and BD-24P produce from the same fault block and would both be good candidates, however well BD-12P is located on WHP-2where there is available facility to allow perform a pilot test without modifications and therefore is the best possible candidate for this pilot test.

\subsection{Reservoir simulation study}

Asthe result of gas injection test, which was carried out in June 2014, confirmed that around 4MMscf/d could be injected into well BD-12P using the current gas-lift compressor which has an outlet compression capacity of 1,700 psig. Therefore a proposed pilot sequence has been simulated using the history matched Eclipse model, with the good history matching for static \& flowing bottom hole pressures, tubing head pressure and watercut (Figure 2).

Table 1. Selection of Proposed Pilot Well / Area

\begin{tabular}{|c|c|c|c|}
\hline No & $\begin{array}{l}\text { GAGD Pilot Application } \\
\text { Criteria }\end{array}$ & Well BD-12P & Well BD-24P \\
\hline 1 & High Current Watercut & $80 \%$ & $87 \%$ \\
\hline 2 & $\begin{array}{l}\text { High HC column in the } \\
\text { wellbore }\end{array}$ & $\begin{array}{l}208 \mathrm{~m} \\
\text { (From F\#6 to TOB) }\end{array}$ & $\begin{array}{l}309 \mathrm{~m} \\
\text { (From F\#1 to TOB) }\end{array}$ \\
\hline 3 & $\begin{array}{l}\text { Low reservoir pressure (Below } \\
\text { Injection Press) }\end{array}$ & $\sim 2150$ psia & 2200psia \\
\hline 4 & $\begin{array}{l}\text { Isolation from other wells / } \\
\text { domains }\end{array}$ & Yes & Yes \\
\hline 5 & $\begin{array}{l}\text { Relatively low oil rate } \\
\text { producer } \\
\text { (low risk, less production } \\
\text { losses during injection period) }\end{array}$ & 330bopd & 340bopd \\
\hline 6 & Other(s) & On WHP-2 & $\begin{array}{l}\text { Twin well with BD-21PST, } \\
\text { Fish in hole, located on WHP- } \\
\text { 1: full deck capacity }\end{array}$ \\
\hline & Final Ranking & 1 & 2 \\
\hline
\end{tabular}




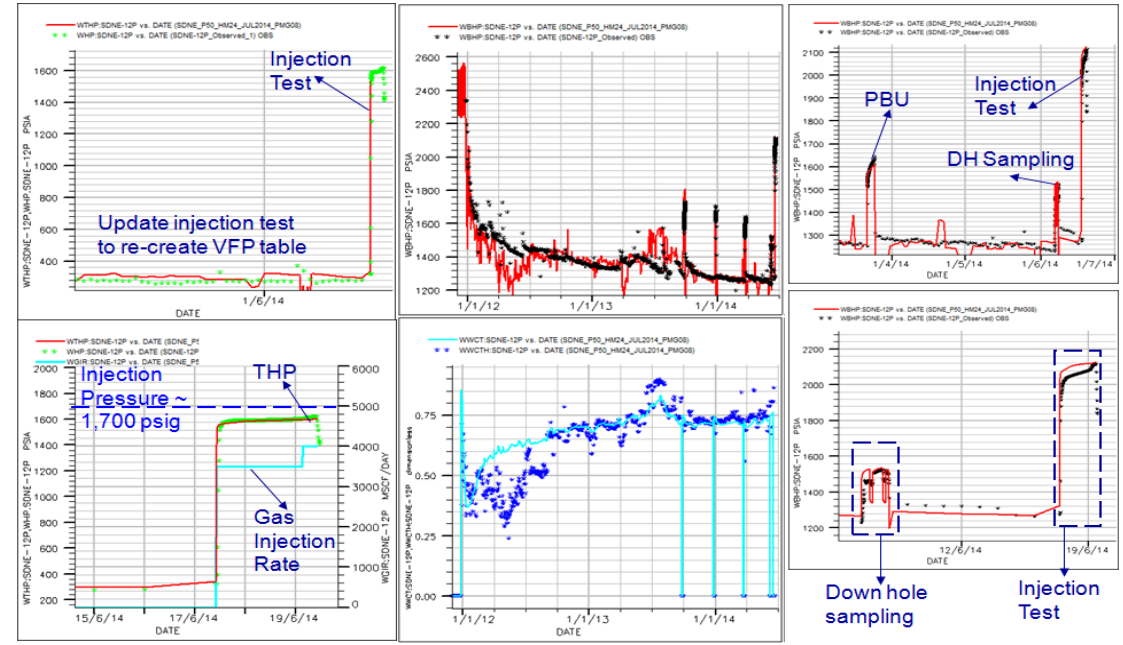

Figure 2. Well BD-12Phistory gas injection test matching
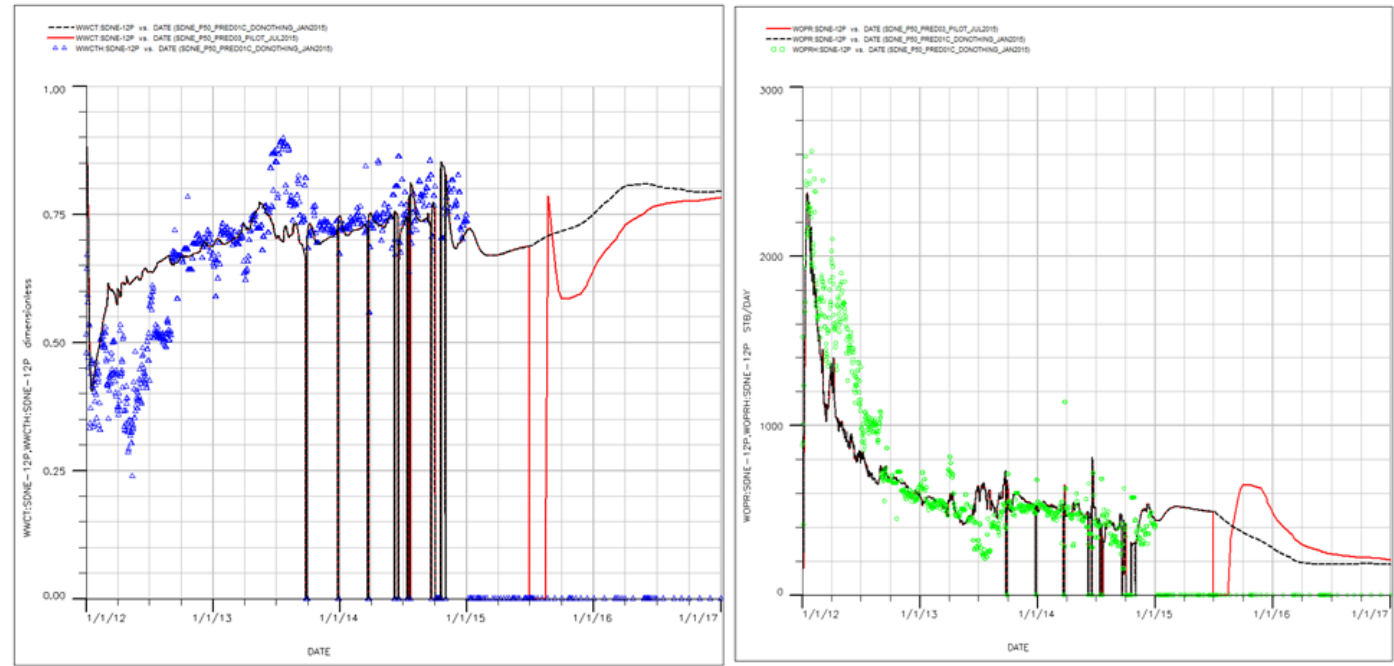

Figure 3. BD-12P simulated well water-cuts \& oil rates withdo-nothing (black) and GAGD pilot (red).

History in blue \& green

Reservoir simulation sensitivities study result have shown attractive gains, by lowering of watercutsand increase in oil rates in BD Basement fault block, in particularly, water cuts are lowered from $72 \%$ to $60 \%$ in well BD-12P, with approximately gain of +200 bopd.
Simulations have also been run for a continuation of the pilot until the end of the contract in September 2023 as shown in figure 4. The increment compared to the Do-nothing case is $3.56 \mathrm{MMstb}$.

\section{Trang 164}




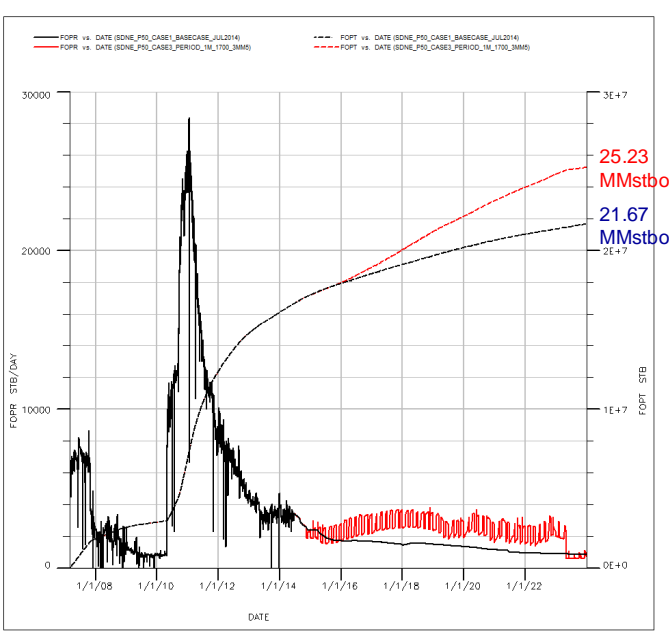

Figure 4. Simulated field oil rates \& cumulative oil withdo-nothing (black) and continued GAGD (red)

\section{Lab Test}

Due to concern on the possibility of asphalting deposition in the near wellbore as the gas meets the reservoir oil that simulation is not able to capture, an asphaltingenvelope study was performed in the lab intensively. The objectives of this asphalting study were to evaluate asphaltenes instability as a function of pressure depletion on reservoir fluid blended with supplied separator gas at reservoir temperature.

Isothermal depressurization experiment
(IDE) was conducted on 55 Mole \% Separator Gas Blend Sample at $266^{\circ} \mathrm{F}$. During the IDE at $266^{\circ} \mathrm{F}$, asphaltene was detected by the near infrared system at 6,955 psig (Figure 5). IDE was also conducted on 40 Mole \% separator gas blend sample at $266^{\circ} \mathrm{F}$ to determine Asphaltene Onset Pressure (AOP) as a second point on the $\mathrm{P}-\mathrm{X}$ diagram. During the isothermal depressurization experiment (IDE) at $266^{\circ} \mathrm{F}$, asphaltene was detected by the near infrared system at 3,694 psig (Figure 6).

Asphaltenes flocculation was detected as a function of depressurization at reservoir temperature $\left(266^{\circ} \mathrm{F}\right)$ for reservoir fluid and hydrocarbon gas mixtures of 40 mole $\%$ and 55 mole \%. The lab results have defined the asphaltene envelope (Figure 7). This envelope is formed from the asphaltene onset pressure (AOP) locus and the bubble point line. The asphaltene deposition wiil only occur in the case reservoir pressure and gas fraction fall within the envelope. Under expected condition (Qinj = $4 \mathrm{MMscf} / \mathrm{d}, \mathrm{BHP}=2,200 \mathrm{psia}$ ) it is not expected to enter the envelope and therefore lab results suggest it is safe to inject gas-lift gas into well BD-12P.

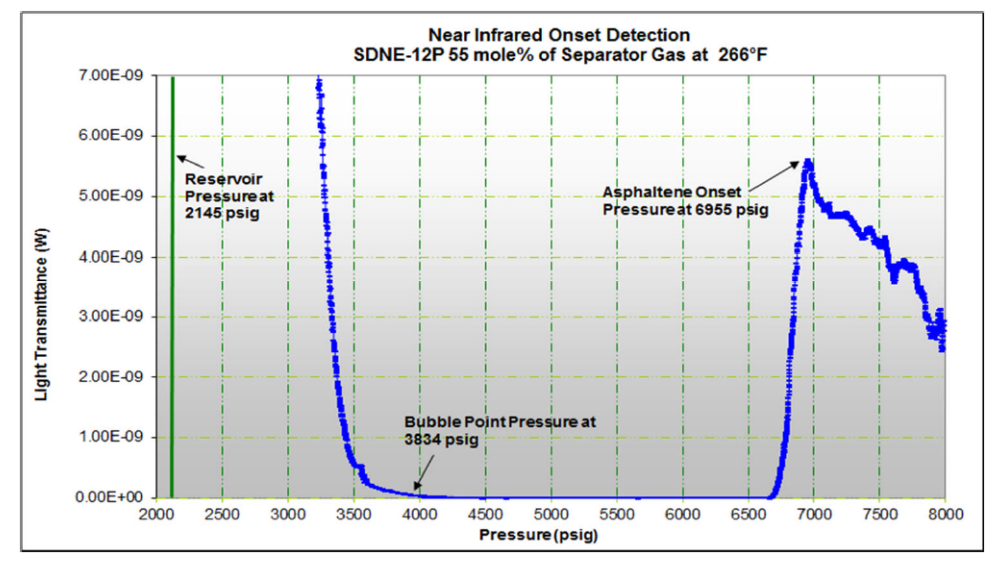

Figure 5. Asphaltene onset evaluation of 55 mole $\%$ gas blend sample at $266^{\circ} \mathrm{F}$ 


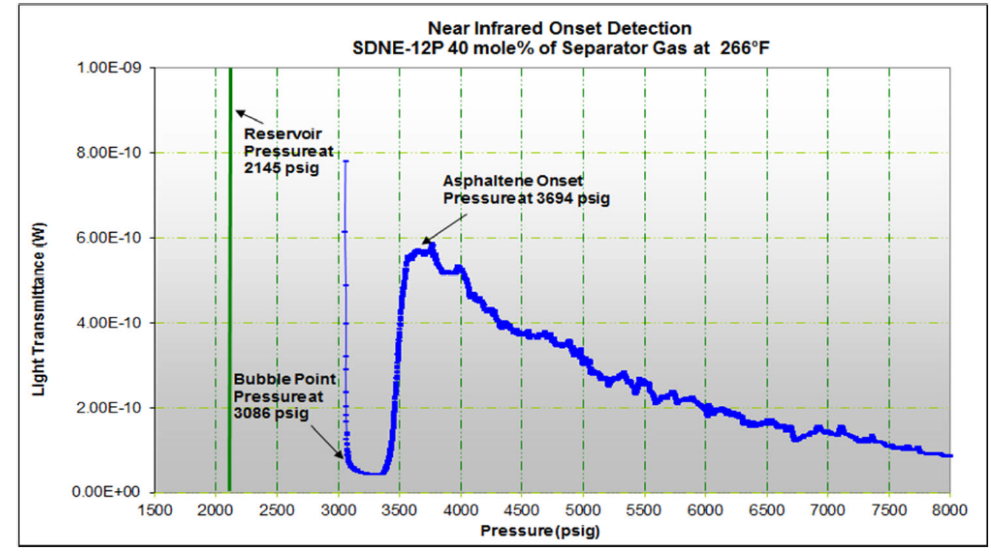

Figure 6. Asphaltene onset evaluation of 40 mole $\%$ gas blend sample at $266^{\circ} \mathrm{F}$

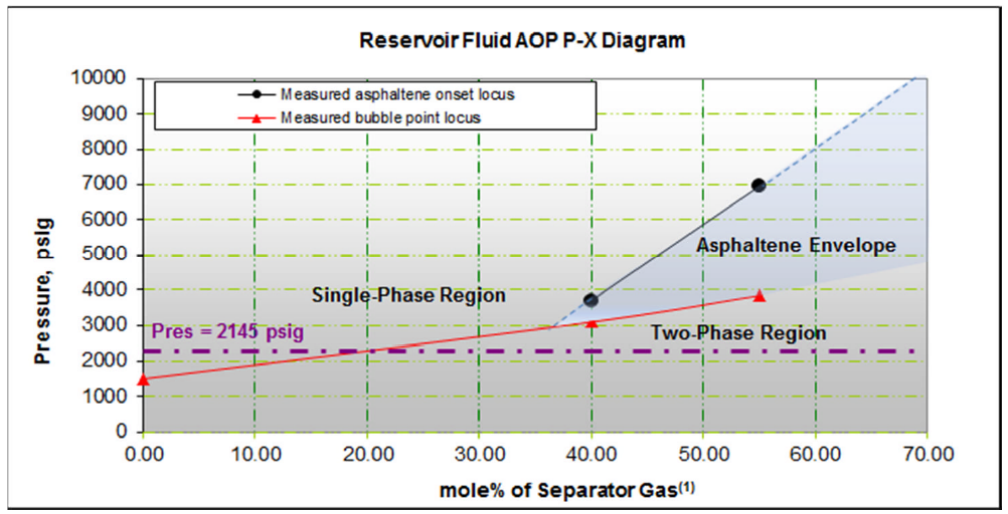

Figure 7. Asphaltene envelope formed from IDE results

\section{CONCLUSIONS}

Based on selection criterias, well BD-12P which currently produces 330bopd plus $80 \%$ watercut, is the best candidate well for GAGD test.

The lab test results confirmed the asphanten free when perform lift gas injection into well BD-12P by existing gas lift compressor.

Reservoir simulation study results for GAGD process in fractured basement reservoir, BD oil field suggested impressive gains in oil production and ultimate reserves are possible by moving the oil-water contact below the producing interval and hence reducing the watercut. Total gains of +200 bopd is estimated with a 1 month slug injection of $4 \mathrm{MMscf} / \mathrm{d}$ of gas, then shut-in for a short "gas migration" period of 2 weeks before finally re-opening the well to production.

Moreover, repeatedly of the gas injection, shut in then producing circle to the end of the project could yield up to 3.56MMbbls.

\section{Discusions}

Despite of the positive forecasts, the project does have some risks associated with it. The main subsurface risks identified are related to non-ideal gas segregation. This could be through:

- Gas not dissolving and/or migrating away from the well-bore sufficiently;

\section{Trang 166}


- Leaking of gas to adjacent areas (and therefore not significantly lowering the OWC);

- Possibly have early gas break throught to near by well BD-24P;

From those above uncertainties strongly suggest to carry out a pilot test first before widely field apply.
Acknowledgement: We gratefully acknowledge the group of research, the subsurface department of Cuu Long JOC for supporting the authors to carry out the study. We also thank Cuu Long JOC for providing the data for our research. This research is funded by Vietnam National University Ho Chi Minh City (VNU-HCM) under grant number B201520-06.

\section{Quá trình phân dị trọng lực trợ giúp bởi bơm ép khí nhằm cải thiện thu hồi dầu trong thân dầu móng nứt nẻ mỏ Báo Đen}

- Nguyễn Văn Tuân

Khoa Kỹ thuật Địa chất \& Dầu khí - Trường Đại học Bách khoa, ĐHQG-HCM và Cửu Long JOC

- Trần Văn Xuân

Khoa Kỹ thuật Địa chất \& Dầu khí - Trường Đại học Bách khoa, ĐHQG-HCM

\section{TÓM TẮT}

Bơm ép khí được sủ dụng rộng rãi trong quá trình IOR/EOR. Không nhu mô hình bơm ép khi điển hình, CGI và WAG, quá trình phân dị trong lục với trơ giúp bởi bom ép khi (GAGD)có ưu thế của quá trình phân dị chất lưu via nhằm bổ sung lực trọng lực một cách ổn định cho quá trình đẩy dầu. Thực tiễn đã chứng minh quá trình đạt hiệu quả cao quét và thay thế vi dầu cao hơn trong vùng dầu sót của via chứa. Do đó khi khô được chọn để bơm ép cho thân dầu móng nứt nẻ mỏ Báo Đen (BD) bể Cưu Long bằng ứng dụng công nghệ GAGD. Tại đây theo lịch sử năm(05) năm khai thác tù chín giếng được trợ áp bởi cơ chế nuớc via tù hai cánh Tây Bắc và Tây Nam. Nóc của thân dầu móng phân bố tại độ sau $2.800 m$ với bề dầy lên đến $1.500 m$. Dư án bơm ép thư GAGD được thiết kế nhằm thư nghiệm trong miền biệt lập của thân dầu móng nưt nẻ mỏ $B D$ có điều kiện thuận lợi cho thí nghiệm GAGD. Cả mô hình mô phỏng vỉa và thí nghiệm trong phòng được tiến hành và khẳng định tính khả thi cũng nhu lợi ich của dụ án GAGD trong khu vục thi nghiệm. Khi khô được borm định kỳ thông qua giếng khai thác có 
tỷ lệ ngập nuớc cao trong khu vục nghiên cứu. Khi khi bơm ép lan đến nóc của thân dầu đã hình thành một đới (mũ) khi đã đẩy ranh giới Khí Dầu dịch chuyển xuống sâu hơn và có khả năng đẩy ranh giới Dầu Nuớc xuống phần đáy của khoảng khai thác giếng này (thậm chí sâu hơn đáy giếng) cho phép giảm hàm luợng ngập nuớc khi giếng được đưa trở lại khai thác. Mô hình (khai thác) via được khớp hóa với tính chất đá chứa và chất lưu via nhằm phân tích độ nhạy của thi nghiệm, kết quả thử nghiệm cho thấy tỷ lệ dầu tăng đáng kể đồng thời tỷ lệ nuớc sản phẩm giảm đáng kể khi áp dụng GAGD. Nhiều kịch bản khác nhau đã được chạy để tìm giải pháp khai thác via tối un bằng quá trình GAGD. Trong nhũng kịch bản này với đối tương nghiên cứu, cần borm ép với luu luợng khí lớn nhằm đạt sản lượng khai thác cộng dồn tối đa.

Tù khóa: Phân dị trọng lực, tăng cường thu hồi, cải thiện thu hồi, GAGD, tầng chứa móng nứt né, bơm ép, đẩy.

\section{REFERENCES}

[1]. Ashgari, K. and Torabi, F., Performance of Huff-and-Puff Process in Fractured Media (Experimental Results), SPE conference paper, Canadian International Petroleum Conference, Jun 12 - 14, 2007, Calgary, Alberta, doi 0.2118/2007-119 (2007).

[2]. Kawahara, Y., Mitsuishi, H., Takagi, S., Okabe, H., Nguyen Hai An, Nguyen Manh Hung, Phan Ngoc Trung, Ueda, Y., Comprehensive Co2-EOR Study - Study on Applicability of Co2-EOR to Rang Dong Field - Part I Laboratory Study, Petrovietnam Journal, Vol 6, 2009.

[3]. Awan, A.R., et al.: "EOR Survey in the North Sea," SPE 99546, presented at
Improved Oil Recovery Symposium, Tulsa, OK (2006).

[4]. Goodlett, G.O., Honarpour, F.T., Chung, F.T., Sarathi, P.S.: The Role of Screening and Laboratory Flow Studies in EOR Process Evaluation, SPE 15172, presented at SPE

[5]. Mohammed-Singh, P., Singhal, A.K., and Sim, S.: "Screening Criteria for Carbon Dioxide Huff 'n' Puff Operations," SPE 100044, presented at the 2006 SPE/DOE Symposium on Improved Oil Recovery (2006). 